\title{
Enterotoxigenic Escherichia coli associated with childhood diarrhoea in Colombia, South America
}

\author{
Oscar G. Gómez-Duarte ${ }^{1}$, Yesenia C. Romero-Herazo ${ }^{1,3}$, Carol Z. Paez-Canro², \\ Javier H. Eslava-Schmalbach ${ }^{2}$, Octavio Arzuza ${ }^{3}$ \\ ${ }^{1}$ International Enteric Vaccine Research Program, Division of Pediatric Infectious Diseases, Vanderbilt University \\ School of Medicine, Nashville, United States \\ ${ }^{2}$ Instituto de Investigaciones Clínicas, Facultad de Medicina, Universidad Nacional de Colombia, Bogotá D.C. \\ Colombia \\ ${ }^{3}$ Departamento de Microbiología, Grupo de Microbiología Clínica y Ambiental, Universidad de Cartagena, \\ Cartagena, Colombia
}

\begin{abstract}
Introduction: Intestinal Escherichia coli pathogens are major causes of diarrhoeal disease in children under five years of age worldwide. The aim of this study is to evaluate the association of E. coli pathotypes with childhood diarrhoea in Colombia.

Methodology: A case-control study was conducted in 815 samples from children younger than five years of age in Cartagena, Colombia (466 cases and 349 controls). Controls were randomly selected 1:1 to cases, to obtain 349 cases and 349 controls.

Results: This study revealed that 27 (7.44\%) cases and $12(3.43 \%)$ controls were positives for any of the E. coli pathotypes. The difference observed was statistically significant indicating that $E$. coli pathotypes were associated with cases of childhood diarrhoea. Enterotoxigenic $E$. coli (ETEC) was the most common pathotype associated with childhood diarrhoea. Additional E. coli pathotypes were also identified. Conclusions: We conclude that after the adjustment by age, sex and socioeconomic stratum, the odds ratio obtained by logistic regression shows an association between infection with ETEC and childhood diarrhoea.
\end{abstract}

Key words: multiplex PCR; enterotoxigenic E. coli; surveillance; diarrhoea; Colombia; EPEC; bundle-forming pilus; localized-adherence E. coli

J Infect Dev Ctries 2013; 7(5):372-381.doi:10.3855/jidc.2667

(Received 27 March 2012 - Accepted 29 July 2012)

Copyright (C) 2013 Gómez-Duarteet al. This is an open-access article distributed under the Creative Commons Attribution License, which permits unrestricted use, distribution, and reproduction in any medium, provided the original work is properly cited.

\section{Introduction}

Acute diarrhoeal disease (ADD) is a serious public health problem in developing countries, and it remains a major cause of morbidity and mortality in children younger than five years of age [1]. In this age group it is estimated that 1.5 to 2.5 million deaths occur annually due to $\mathrm{ADD}$, that is, about 10 deaths every minute [2,3]. Among all etiological agents implicated in the causation of childhood diarrhoea, intestinal Escherichia coli pathogens are believed to be the second most frequent pathogens after rotavirus [4,5]. The identification of $E$. coli pathotypes in association with diarrhoea has been limited in many developing countries because conventional microbiological testing is unable to distinguish between normal flora and pathogenic strains of $E$. coli. There are six different intestinal E. coli pathotypes associated with diarrhoea, including enteropathogenic (EPEC), shiga-toxin producing (STEC), enterotoxigenic (ETEC), enteroinvasive (EIEC), enteroaggregative (EAEC), and diffuse adherent $E$. coli (DAEC) [6,7].

Detection of intestinal E. coli pathogens is most commonly performed by DNA amplification technology, including multiplex polymerase reaction (PCR) assay or PCR-free detection assays [8-10]. While DNA detection technology implementation is costly and technically challenging in many countries with limited resources, recent technology has been reported that may facilitate the performance of these assays in areas with inadequate or absent freezing conditions (our unpublished results) or even in areas with no electric power [11]. Information obtained on 
intestinal E. coli pathogens through these assays is the basis for the epidemiological surveillance information on which national and international public health authorities depend to implement preventive measures, recommend pathogen-specific medical management, and invest in vaccine development research.

The country of Colombia has 44 million inhabitants, $27.7 \%$ under the age of 15 years of age, with $77 \%$ of the population living in urban areas. The Colombian infant mortality rate is 16.9 deaths per 1,000 live births, which places the country in $111^{\text {th }}$ place out of 229 nations [12]. In Colombia, diarrhoea is the second most common cause of morbidity after respiratory infections, with a rate of 110 cases per 100,000 inhabitants [13]. Very few studies are available on the role of specific etiologic agents associated with diarrhoea, and limited epidemiological surveillance is being implemented. Studies report that rotavirus is associated with a significant number of cases of diarrhoea [14-18]. Limited studies report the role of bacterial pathogens, including Shigella, Salmonella, and $V$. cholerae, in causing childhood diarrhoea $[13,17,19,20]$.

A recent prevalence study in two Caribbean cities in Colombia reported that $14.4 \%$ of all E. coli clinical isolates tested and $7.5 \%$ of all stool specimens tested were positive for intestinal $E$. coli pathogens. The pathotypes identified included ETEC, STEC, EAEC, DAEC, and EPEC, with ETEC being the most common pathotype [21]. Some E. coli clinical isolates had more than one virulence gene detected and were designated as mixed pathotypes [22]. In addition to clinical isolate testing, a similar study was conducted on food products from retail stores in Colombia to evaluate their contamination with intestinal E. coli pathogens. Using the same two-sample PCR assay, it was shown that $7.9 \%$ of all food products were positive for $E$. coli pathotypes, including mixed pathotypes [23]. The clinical significance of these $E$. coli isolates could not be determined by these studies, as no control group was evaluated.

To evaluate the association of classic E. coli pathotypes and emergent $E$. coli with childhood diarrhoea in Cartagena, Colombia, a case control study was conducted. The goals of this study included the detection of classic intestinal E. coli pathogens in stool samples from children with or without ADD, detection of emergent $E$. coli intestinal pathogens, and evaluation of the association between intestinal E. coli pathogens and childhood diarrhoea.

\section{Methodology}

Study design

A case-control study was conducted to evaluate the association of $E$. coli pathotypes with diarrhoea in children younger than 5 years of age in Cartagena, Colombia. From an original database of 815 samples (349 controls and 466 cases), samples were randomly selected to reach a ratio of 1:1 of cases and controls without pairing for any variable, for a total of 349 pairs. To be eligible for the study the following inclusion criteria had to be fulfilled by case subjects: (a) Being children less than five years of age; (b) Having diarrhoea that fulfill the WHO criteria for ADD [24]. The inclusion criteria for controls were as follows: being children less than 5 years of age without diarrhoea. The exclusion criteria for participation included (a) having diarrhoea lasting more than seven days; (b) having a history of antibiotics use up to a month before enrollment. A questionnaire was used to collect subject information, including age, sex, area of residence, socio-economic stratum, days of diarrhoea, and date of collection. Area of residence was matched to socio-economic strata according to Colombian government city zoning legislation in which socioeconomic stratum 1 corresponded to areas with the lowest community living conditions and stratum 6 to areas with the highest community living conditions [25]. No specimens from subjects from socioeconomic ranks 5 and 6 were reported in this study, as the university hospital where this work was conducted was not accessed by individuals from these ranks.

The information was added to a database that was kept confidential throughout the study. Stool samples from children with diarrhoea were collected from a population being evaluated at the university hospital Napoleon Franco Pareja Children's Hospital. Stool samples from controls were collected from the same hospital and from day-care centers in neighborhoods surrounding the Children's Hospital. This study was approved by the Ethics Committee at the University of Cartagena, and the Napoleon Franco Pareja Children's Hospital. Informed consent was obtained from the children's parents before samples were collected.

\section{Sample collection and processing}

Between May 2009 and May 2010, 466 stool samples from cases and 349 stool samples from controls were obtained. Stool samples collected were immediately processed. Alternatively, samples were transported at $4^{\circ} \mathrm{C}$ from the collection site to the University of Cartagena Research Laboratory for same 
day sample processing. A single E. coli isolate was obtained from each stool sample by culturing stool on McConkey agar, and subculturing on Eosin methylene blue agar for the isolation of pure strains. Lactosefermenting Gram-negative coccobacilli were tested and identified by traditional biochemical tests. Presumptive E. coli strains capable of fermenting lactose, beta-glucuronidase, positive indol, negative citrate, and positive motility were confirmed as E. coli $[23,26]$. All E. coli clinical isolates from cases and controls were isolated and preserved at $-70^{\circ} \mathrm{C}$ in $20 \%$ glycerol and tryptone soya broth (TSB) (Merck, Darmstadt, Germany).

\section{Multiplex PCR}

E. coli clinical isolates were processed for isolation of genomic DNA as described before. In brief, overnight liquid cultures were centrifuged and the pellet resuspended in $1 \mathrm{ml}$ of TE buffer $(10 \mathrm{mM}$ Tris- $\mathrm{HCl} \mathrm{pH} \mathrm{8.0,5} \mathrm{mM} \mathrm{EDTA),} \mathrm{incubated} \mathrm{at} 96^{\circ} \mathrm{C}$ for 5 minutes, and centrifuged for 10 minutes. The supernatant containing crude genomic DNA was used as a DNA template on a two-sample multiplex PCR reaction for identification of $E$. coli pathotypes. The two-sample multiplex PCR was performed as previously described [21]. In brief, genomic DNA from classic $E$. coli pathotypes was used as positive controls and genomic DNA from E. coli HB101 laboratory strain was used as negative controls, as described earlier [8]. The PCR reaction 1 contained M1 primers for amplification of eae, $b f p A, \mathrm{VT}$, and $\operatorname{aggR}$ gene targets for identification of STEC, EPEC, and EAEC pathotypes. The PCR reaction 2 contained M2 primers for amplification of LT, ST, daaE, ipaH, and virF gene targets for identification of ETEC, DAEC, and EIEC pathotypes. Each PCR reaction contained $1 \mu 1$ of genomic DNA mixed with $24 \mu 1$ of a pre-made mix of primers at a $0.2-\mu \mathrm{M}$ final concentration and Taq polymerase (Platinum Blue PCR SuperMix, Invitrogen, Carlsbad, CA). The PCR program used for amplification consisted of 2 minutes at $94^{\circ} \mathrm{C}$ of denaturing temperature, followed by 40 cycles of 30 seconds at $92^{\circ} \mathrm{C}$ of denaturing temperature, 30 seconds at $59^{\circ} \mathrm{C}$ of annealing temperature, and 30 seconds at $72^{\circ} \mathrm{C}$ of extension temperature. At the end of the 40 cycles and a 5minute extension at $72^{\circ} \mathrm{C}$, samples were separated onto a $2 \%$ agarose ethidium bromide stained gel, and DNA bands were visualized and recorded under ultraviolet light for further analysis.

$E$. coli strains that tested positive were confirmed by single PCR. In addition, generic Shiga-toxin (stx) primers were further tested for stx-1 and/or stx-2 DNA targets by a single PCR assay using specific forward and reverse primer pairs as described previously $[23,27,28]$.

\section{Statistical analysis}

Data from cases and controls were analyzed by the GraphPad InStat software program version 3.06 (GraphPad Software, Inc, La Jolla, CA, USA). For all statistical calculations a $p$-value of 0.05 was stated as statistically significant. Data from cases and controls were analyzed using independent sample statistics. The total population ( 815 children) was randomly selected to obtain 349 cases for 349 controls without matching for any variable to obtain a ratio of $1: 1$ and to eliminate the potential bias given by the original difference in the number of cases with respect to controls. The total number of subjects was 698 . Frequencies of cases and controls positive for each one of the E. coli pathotypes detected were calculated. Univariate logistic regression analysis of odds ratios (OR) was performed. Multivariate logistic regression analysis was conducted to determine the association of a particular E. coli pathotype with acute diarrhoea when controlled by sex, age, and/or socio-economic level. Excel software (Microsoft, Redmond, WA, USA) was used for data storage. Random selection of cases and the statistical analysis were performed with the STATA/SE 11.0 software (StataCorp LP, College Station, TX, USA).

\section{Results}

\section{Characteristics of study population}

Data were collected at a single point in time from a total of 815 children younger than 5 years of age. For this study 466 diarrhoea stool samples were collected from children with diarrhoea (cases) and 349 samples from children without diarrhoea (controls). The initial population of 815 children was reduced to 698 by random selection to obtain a case-control ratio of 1:1. The characteristics of the study population after randomization are described in Table 1. Based on interquartile (IQR) age range measurements, the cases had a tendency to be older than the controls, with cases with a median age of three years (IQR $2-4)$ and Controls with a median age of two years median (IQR 1 - 4) (Table 1). Based on the Mann Whitney test there was a statistically significant difference $(\mathrm{p}<$ 0.001 ) among age ranges between the two groups.

The time range of diarrhoea before enrollment in the study was between one and seven days in cases. Cases were also more frequent among the lower socio- 
Table 1. Study population of children younger than 5 years of age with and without diarrhoea in Cartagena, Colombia

\begin{tabular}{|c|c|c|c|c|c|c|}
\hline Characteristic & $\begin{array}{c}\text { CASES } \\
\text { (349) }\end{array}$ & $\begin{array}{c}\text { CONTROLS } \\
\text { (349) }\end{array}$ & TOTAL & $p$-value & OR crude* & IC $95 \%$ \\
\hline Age & $\begin{array}{l}\text { (Me: } 4 \text { years; } \\
\text { IQR (2-4)) }\end{array}$ & $\begin{array}{l}\text { (Me: } 3 \text { years; } \\
\text { IQR (2-4)) }\end{array}$ & & 0.000 & 0.79 & $0.71-0.88$ \\
\hline Sex & & & & 0.624 & 0.92 & $0.66-1-27$ \\
\hline Females n $(\%)$ & $151(48.87)$ & $158(51.13)$ & 309 (44.59) & & & \\
\hline Males n (\%) & $198(51.56)$ & $186(48.44)$ & $384(55.41)$ & & & \\
\hline Stratum & & & & 0.000 & 0.31 & $0.23-0.40$ \\
\hline One $n(\%)$ & $273(78)$ & $137(40.18)$ & $410(59.42)$ & & & \\
\hline Two $\mathrm{n}(\%)$ & $59(16.91)$ & $143(41.94)$ & $202(29.28)$ & & & \\
\hline Three n (\%) & $17(4.87)$ & $32(9.38)$ & $49(7.10)$ & & & \\
\hline Four $\mathrm{n}(\%)$ & $29(8.50)$ & $0(0)$ & $29(4.20)$ & & & \\
\hline E. coli & & & & 0.22 & 0.83 & $0.61-1-12$ \\
\hline$(+) \mathrm{n}(\%)$ & $188(53.87)$ & $204(58.45)$ & $392(56.16)$ & & & \\
\hline$(-) \mathrm{n}(\%)$ & $161(46.13)$ & $145(41.55)$ & $306(43.84)$ & & & \\
\hline
\end{tabular}

$\mathrm{OR}=$ odds ratio

* Crude odds ratio calculated by logistic regression

economic strata compared with controls. These data suggest that the higher socioeconomic stratum is associated with protection against diarrhoea (Table 1). The proportion of male and female subjects was similar among cases and controls, there was no significant difference with respect to diarrhoea association, and the number of E. coli strains isolated from cases and controls was the same (Table 1).

\section{E. coli pathotypes identified among isolates}

E. coli strains isolated from all stools from children with and without diarrhoea were analyzed for the presence of $E$. coli and $E$. coli intestinal pathotypes by the two-sample multiplex PCR assay. The presence of $E$. coli strains was similar among cases and controls (Tables 2 and 3). A total of $188(53.87 \%)$ cases were positive for E. coli strains and 204 (58.87\%) for controls. Twenty-six (7.44\%) strains in cases and 12 $(3.43 \%)$ in controls were positive for $E$. coli pathotypes (Table 2 and Table 3), indicating that 38 $(5.44 \%)$ from the total stool samples collected were positive for E. coli intestinal pathotypes (Table 3).

Logistic regression analysis confirmed the statistically significant differences in age between cases and control groups. The ORs suggested that age and socioeconomic strata may have a protective effect on the development of diarrhoea (Table 4). Both age and socioeconomic strata were confounding variables that may have led to the underestimation of the effect of infection with these strains in the development of ADD (Table 2). Results from the logistic regression analysis confirmed the statistically significant differences in age between the two groups (Table 4). The adjusted OR suggests a protective age effect to develop diarrhoea.

Table 2. Distribution of E. coli pathotypes between cases and control groups

\begin{tabular}{lccc}
\hline & $\begin{array}{c}\text { CASES } \\
\mathbf{n}=\mathbf{3 4 9} \\
\mathbf{n}(\mathbf{\%})\end{array}$ & $\begin{array}{c}\text { CONTROLS } \\
\mathbf{n}=\mathbf{3 4 9}\end{array}$ & $\begin{array}{c}\text { TOTAL } \\
\mathbf{n}=\mathbf{6 \% )}\end{array}$ \\
Strain & $\mathbf{n}(\mathbf{\%})$ \\
\hline EPEC & $5(1.43 \%)$ & $1(0.29 \%)$ & $6(0.86 \%)$ \\
EAEC & $1(0.29 \%)$ & $3(0.86 \%)$ & $4(0.57 \%)$ \\
ETEC & $17(4.87 \%)$ & $8(2.29 \%)$ & $25(3.58 \%)$ \\
EIEC & $1(0.29 \%)$ & $0(0 \%)$ & $1(0.14 \%)$ \\
Mix & $2(0.29 \%)$ & $0(0 \%)$ & $2(0.29 \%)$ \\
Total & $\mathbf{2 6 ( 7 . 4 4 \% )}$ & $\mathbf{1 2 ( 3 . 4 3 \% )}$ & $\mathbf{3 8 ( 5 . 4 4 \% )}$ \\
\hline
\end{tabular}


Table 3. Distribution of samples among children with or without diarrhoea with respect to presence of $E$. coli

\begin{tabular}{|c|c|c|c|c|c|c|c|c|c|c|}
\hline \multirow[t]{3}{*}{ Samples } & \multirow{2}{*}{\multicolumn{2}{|c|}{ Negative for $E$. coli }} & \multicolumn{6}{|c|}{ Positive for $E$. coli } & \multicolumn{2}{|c|}{ Total } \\
\hline & & & Non- & ogenic $^{\mathrm{a}}$ & Pat & senic $^{b}$ & & & & \\
\hline & $\mathrm{n}$ & $\%$ & $\mathrm{n}$ & $\%$ & $\mathrm{n}$ & $\%$ & $\mathrm{n}$ & $\%$ & $\mathrm{n}$ & $\%$ \\
\hline Cases & 161 & 52.62 & 162 & 46.76 & 26 & 68.42 & 188 & 47.96 & 349 & 50.0 \\
\hline Controls & 145 & 47.38 & 192 & 54.24 & 12 & 37.58 & 204 & 52.04 & 349 & 50.0 \\
\hline Total & 306 & 100.00 & 354 & 100.00 & 38 & 100.00 & 392 & 100.00 & 698 & 100.00 \\
\hline
\end{tabular}

ETEC strains were the most frequent E. coli pathotypes and were associated with childhood diarrhoea. ETEC was more prevalent among cases. ETEC strains had the highest absolute frequency of positive results, with $17(4.87 \%)$ in cases and 8 $(2.29 \%)$ in controls (Table 2). This data was subsequently evaluated by logistic regression to establish the relationship among individual variables with respect to cases or controls and after controlling for age, sex and socioeconomic stratum (Table 4). The OR demonstrates that ETEC is more prevalent among cases and that there was a 2.5 fold increased risk of having ETEC in cases with diarrhoea than in individuals without diarrhoea (controls).

Based on the presence of enterotoxin, 11 (44\%) ETEC isolates were LT positives, 10 (40\%) were ST positive and only $4(16 \%)$ were LT/ST positive (Table 5). Seven LT positive ETECs were isolated from control subjects, while only one was ST positives. Cases had a combination of LT, ST, or LT/ST ETEC strains. Control individuals positive for ETEC were one year old or older. In contrast, cases positive for ETEC included individuals two months old to five years old (Table 5).

Additional E. coli pathotypes among clinical isolates from children with and without diarrhoea

Additional known E. coli intestinal pathogens were identified, including EPEC, STEC, EAEC and EIEC strains (Table 2). No statistically significant association was established between these strains and $\mathrm{ADD}$, as the frequencies in cases and controls were very low. EPEC strains were the second most common pathotype with five $(1.43 \%)$ strains among cases and one $(0.29 \%)$ strain among controls. While this frequency is not statistically significant, the difference between cases and controls having EPEC infection was $4.01 \%$ (Table 4). EPEC strains are defined genetically by the presence of the LEE pathogenicity island, which encodes a type III secretion system capable of inducing the attaching and effacing lesion phenotype. While typical ETEC strains also carry $b f p$ genes, atypical EPEC, the most frequent group, lack $b f p$ genes. Two out of six EPEC isolates were typical EPEC and were isolated from cases (Table 6).

EAEC strains were identified in one case and three controls. Presence of EAEC is therefore not associated with diarrhoea in this study. Only one EIEC strain was identified in a case. Since no EIEC strains were detected in controls no logistic regression analysis was conducted (Table 4).

Identification of mixed E. coli pathotypes in children with diarrhoea

A total of three strains designated mixed E. coli pathotypes were identified among children with diarrhoea in the initial screening of 815 samples and two from the randomized study (Table 6). Mixed pathotypes are defined as those having a virulence genotype different from known E. coli pathogens. No mixed pathotypes were identified from controls. Two $E$. coli strains were positive for the EAEC $a g g R$ marker plus additional virulence factors not typical of EAEC. One of the strains was also positive for LT, a known ETEC marker. The second strain was positive for eae and $b f p A$, which are EPEC markers. These results indicate that these two strains are a combination of EAEC-ETEC and EAEC-EPEC 
Table 4. Odds ratio and $95 \%$ confidence intervals among study variables and case-control groups

\begin{tabular}{lccc}
\hline VARIABLE & Odds ratio & IC 95\%* & $P$-value \\
\hline Edad & 0.80 & $0.71-0.89$ & 0.00 \\
Sex & 0.89 & $0.66-1.20$ & 0.66 \\
Stratum & 0.30 & $0.23-0.40$ & 0.00 \\
E. coli & 0.75 & $0.55-1,03$ & 0.07 \\
EPEC & 5.92 & $0.68-51.23$ & 0.10 \\
EAEC & 0.39 & $0.04-3.83$ & 0.42 \\
ETEC & 2.51 & $1.05-5.98$ & 0.037 \\
\hline * Adjusted OR calculated by logistic regression &
\end{tabular}

pathotypes and may be considered emergent pathogens. Since no strains were obtained from controls no logistic regression analysis could be done to demonstrate disease association (Table 4). A third $E$. coli clinical isolate was identified as $b f p A+/ e a e-$ from the original 466 cases and none from controls. This strain was randomly excluded from the subsequent statistical analysis. This strain is not an EPEC strain as the eae gene is absent, yet the $b f p A$ structural subunit gene for the BFP pili was present (Table 6).

\section{Discussion}

Acute diarrhoeal disease is a leading cause of morbidity and mortality in developing countries, and E. coli pathogens are the second most common cause of diarrhoea worldwide after rotavirus [1,2,29]. Epidemiological data on the role of E. coli intestinal pathogens in childhood diarrhoea in many developing countries is scattered, as detection of these pathogens requires DNA amplification technology, not readily available in countries with limited resources. We report the first case-control study performed in Colombia to evaluate the association of E. coli intestinal pathogens with childhood diarrhoea. Analysis of the data indicates that E. coli intestinal pathogens are associated with childhood diarrhoea in Cartagena, Colombia, and that ETEC is the most frequent $E$. coli pathogen. In addition, we have also identified other known $E$. coli pathotypes and report the presence of potentially novel pathotypes not previously reported in Colombia.

The association of $E$. coli intestinal pathogens with childhood diarrhoea in Colombia has also been described in other Latin American countries by casecontrol studies. In Brazil it was reported that E. coli intestinal pathogens were the second most common cause of diarrhoea after rotavirus [30]. In Chile E. coli pathogens were implicated in childhood diarrhoea in children less than 1 year of age [31]. Studies in Mexico also recognize the importance of $E$ coli in childhood diarrhoea and in asymptomatic infections. A more recent Mexican case-control study reported that in more than $50 \%$ of cases of diarrhoea there was more than one pathogen implicated, including any combination of E. histolytica, Salmonella, or E. coli pathogens [33]. Case-control studies reported from Argentina have concentrated more on STEC, as this country has a high incidence of hemolytic uremic syndrome associated with $\mathrm{O} 157: \mathrm{H} 7$ and non-O157:H7 STEC strains [34].

ETEC was the most frequently isolated $E$. coli intestinal pathogen among children with diarrhoea in our study. This association is statistically significant before and after adjusting for sex and socioeconomic rank by logistic regression. The ORs show that ETEC in cases is more prevalent than in controls. It also shows that exposure to ETEC has a 2.5 fold increased risk for developing diarrhoea than no exposure. Socioeconomic strata level was associated with a protective effect. This may be the result of a better potable water supply and sanitation conditions on communities living in at high socio-economic levels. These data corroborate the previously reported prevalence data, in which ETEC was the most frequent pathogen isolated from children with diarrhoea in Cartagena, Colombia [21]. ETEC is estimated to cause 200 million cases of diarrhoea yearly, leading to 150,000 deaths [35]. Several countries in the world report ETEC as the most common cause of diarrhoea among all E. coli intestinal pathotypes, among them Bangladesh, Egypt and Mexico [36-38]. In addition, ETEC is known to be the most frequent cause of traveller's diarrhoea [3941]. In other countries in Latin America, however, ETEC may not be as frequent as in Colombia. In Brazil, for instance, the most prevalent E. coli intestinal pathogens are EAEC and EPEC [42,43]. While children with diarrhoea positive for ETEC included children from all ages, controls positive for ETEC were older than one year of age. We speculate that a proportion of children one year of age and above who are exposed to ETEC become normal carriers.

This study also identified EPEC, EAEC, and EIEC. The number of isolates was low and there was no statistically significant association with ADD. EPEC isolates were the second most frequent $E$. coli 
Table 5. ETEC Toxin type among cases and controls

\begin{tabular}{|c|c|c|c|c|c|c|}
\hline \multirow{2}{*}{ Clinical isolate } & \multirow{2}{*}{ Age } & \multirow{2}{*}{ Sex } & \multirow{2}{*}{ Diarrhoea } & \multicolumn{3}{|c|}{ Toxin gene } \\
\hline & & & & LT & ST & LT/ST \\
\hline COCt013cc & 5 years & $\mathrm{M}$ & - & + & - & - \\
\hline COCt067cc & 4 years & $\mathrm{F}$ & - & + & - & - \\
\hline COCt090cc & 2 years & M & - & + & - & - \\
\hline COCt140cc & 1 years & $\mathrm{F}$ & - & - & + & - \\
\hline COCt149cc & 1 years & M & - & + & - & - \\
\hline COCt155cc & 3 years & $\mathrm{F}$ & - & + & - & - \\
\hline COCt275cc & 2 years & M & - & + & - & - \\
\hline COCt302cc & 1 years & $\mathrm{F}$ & - & + & - & - \\
\hline $\mathrm{COCt} 023$ & 5 years & $\mathrm{M}$ & + & + & - & - \\
\hline COCt026 & 2 years & $\mathrm{F}$ & + & - & - & + \\
\hline COCt112 & 2 months & $\mathrm{M}$ & + & + & - & - \\
\hline COCt122 & 2 years & M & + & - & + & - \\
\hline COCt124 & 2 months & M & + & - & - & + \\
\hline COCt129 & 2 months & $\mathrm{F}$ & + & - & + & - \\
\hline COCt131 & 5 months & $\mathrm{F}$ & + & + & - & - \\
\hline COCt142 & 3 months & $\mathrm{F}$ & + & - & + & - \\
\hline COCt159 & 2 years & $\mathrm{M}$ & + & - & + & - \\
\hline COCt161 & 2 years & $\mathrm{F}$ & + & - & + & - \\
\hline COCt193 & 1 years & $\mathrm{F}$ & + & - & + & - \\
\hline COCt201 & 3 years & $\mathrm{F}$ & + & - & - & + \\
\hline COCt234 & 2 years & M & + & - & - & + \\
\hline COCt253 & 3 years & $\mathrm{M}$ & + & - & + & - \\
\hline COCt254 & 5 years & $\mathrm{M}$ & + & - & + & - \\
\hline COCt285 & 7 months & $\mathrm{M}$ & + & - & + & - \\
\hline COC337 & 7 months & M & + & + & - & - \\
\hline
\end{tabular}

*Clinical isolates from control subjects without clinical complains at the time of stool collection

Table 6. Features of non-ETEC E. coli pathotypes from cases and controls

\begin{tabular}{|c|c|c|c|c|c|}
\hline Strain & Age & Sex & Diarrhoea & Pathotype & Genes \\
\hline COCt101cc & 5 years & $\mathrm{F}$ & - & Atypical EPEC & eae \\
\hline COCt 125 & 1 month & $\mathrm{F}$ & + & Atypical EPEC & eae \\
\hline COCt 181 & 1 years & M & + & Typical EPEC & eae, bfp $A$ \\
\hline COCt 188 & 5 years & $\mathrm{M}$ & + & Atypical EPEC & eae \\
\hline COCt 192 & 1 month & M & + & Atypical EPEC & eae \\
\hline COCt 302 & 7 months & $\mathrm{F}$ & + & Typical EPEC & $e a e, b f p A$ \\
\hline $\mathrm{COC} 178 \mathrm{cc}$ & 11 months & $\mathrm{F}$ & - & EAEC & $\operatorname{agg} R$ \\
\hline COC179cc & 5 years & M & - & EAEC & $\operatorname{agg} R$ \\
\hline COCt 347 & 5 years & M & + & EAEC & $\operatorname{agg} R$ \\
\hline COCt414 & 11 months & M & + & EIEC & virF, ipaH \\
\hline COCt137 & 5 years & M & + & Mix & $\operatorname{aggR,\mathrm {LT}}$ \\
\hline COCt143 & 2 years & M & + & Mix & $a g g R, e a e, b f p A$ \\
\hline COCt336* & 2 years & $\mathrm{M}$ & + & Mix & $b f p A+, e a e-$ \\
\hline
\end{tabular}

*E. coli clinical isolate from a case not included in the randomized case-control study 
intestinal pathogen in this study; four strains were atypical EPEC and two were typical EPEC.

Two E. coli strains from the randomized casecontrol study and an additional strain from the original number of samples did not fit the definition of classical diarrhoeagenic E. coli. Two of them were positive for the EAEC aggR marker but they also had either the LT ETEC marker or the eae and $b f p A$ EPEC markers. This observation suggests that the virulence plasmid of an EAEC strain may have horizontally transferred to ETEC and EPEC recipient strains or vice versa. We speculate that these strains are not only pathogenic but perhaps more virulent than their ancestral pathotypes, as they may express two independent sets of virulence factors. A third $E$. coli strain had a genotype identified as $b f p A+/ e a e-$. Since this strain is eae-, it is not an EPEC strain, yet the presence of $b f p A+E$. coli strains have not been previously described as pathogenic. We speculate that $b f p A+/ e a e-E$. coli strains may express unknown virulence factors to make these strains pathogenic to humans. We propose that these three genotypes obtained from children with diarrhoea and not from controls may correspond with emergent diarrhoeagenic E. coli strains. E. coli clinical isolates described as mixed pathotypes were previously described from prevalence studies of children with diarrhoea in Colombia and Costa Rica [44]. Since no control group was evaluated in these studies no association with diarrhoea could be established.

Several limitations were identified in this study, including the single $E$. coli isolate per stool sample collected rather than five isolates per stool as recommended by other investigators [45]. Also, the lack of information on other pathogens may contribute to diarrhoea in children younger than five years of age, including enteric viruses, non- $E$. coli bacteria, and enteric parasites. However, this study did not pair cases to controls by age or socioeconomic rank; instead, a multivariate analysis was performed to control the effect on these variables. Future studies in this geographic region that follow these recommendations may provide a more accurate number of $E$. coli pathotypes associated with childhood diarrhoea, recognize the importance of $E$. coli pathotypes with respect to other pathogens, and determine the frequency of mixed infections among cases and controls. More studies will be necessary to investigate the prevalence of emergent diarrhoeagenic E. coli in childhood diarrhoea compared with other diarrhoeal pathogens. The natural history of acute diarrhoeal disease associated with these new strains should also be analyzed by prospective or retrospective epidemiological studies. These studies may provide information on clinical manifestations including type of diarrhoea, degree of dehydration, level of inflammation, associated symptoms, and complications.

Research on the nature of emergent E. coli pathogenesis is currently underway. Genomic sequencing and phylogenetic analysis will provide information on potential virulence factors associated with ADD that may have been horizontally transferred into the emergent $E$. coli genome by virulence plasmids, pathogenicity islands, or bacteriophages. Horizontal transfer of genetic material may be the explanation for the emergence of these pathogens, just as transfer of genetic material is the explanation for the emergence of the E. coli O104:H4 Shiga toxinproducing EAEC pathogen that resulted in the 2011 outbreak of hemolytic-uremic syndrome in Germany. In these particular strains, the Shiga-toxin-phage typical for EHEC strains may have been horizontally transferred to the genome of a typical EAEC strain already harboring a virulence plasmid encoding EAEC virulence genes $[46,47]$.

\section{Conclusion}

In summary, this is the first randomized casecontrol study done in Colombia to evaluate the role of diarrhoeagenic E. coli strains in childhood diarrhoea. The study found that ETEC is the most frequent $E$. coli pathogen associated with childhood diarrhoea and that other diarrhoeagenic $E$. coli, including emergent E. coli pathotypes detected in children, may contribute to ADD in Colombia.

\section{Acknowledgements}

This work was supported in part by RWJF Grant No 65879 through the Harold Amos Medical Faculty Development Program awarded to O.G.G.D., as well as by funding from the University of Cartagena School of Medicine. We are indebted to the administrative and clinical laboratory personnel at the Napoleon Franco Pareja Children's Hospital and daycare centers associated with the Instituto Colombiano de Bienestar Familiar (ICBF) in Cartagena, Colombia. We are grateful to Katry Perez Martinez, Soad Aguado Torres, Jing Bai, and Julio Guerra for technical assistance. We are also thankful to Maria Tamborski and Joanna Wulfsberg for helpful advice and editing of the manuscript.

\section{References}

1. Guerrant RL, Kosek M, Moore S, Lorntz B, Brantley R, Lima AA (2002) Magnitude and impact of diarrheal diseases. Arch Med Res 33: 351-355. 
2. Kosek M, Bern C, Guerrant RL (2003) The global burden of diarrhoeal disease, as estimated from studies published between 1992 and 2000. Bull World Health Organ 81: 197204.

3. Thielman NM, Guerrant RL (2004) Clinical practice. Acute infectious diarrhea. N Engl J Med 350: 38-47.

4. Black RE, Merson MH, Hug I, Alim AR, Yunus M (1981) Incidence and severity of rotavirus and Escherichia coli diarrhoea in rural Bangladesh. Implications for vaccine development. Lancet 1: 141-143.

5. Clarke SC (2001) Diarrhoeagenic Escherichia coli--an emerging problem? Diagn Microbiol Infect Dis 41: 93-98.

6. Kaper JB, Nataro JP, Mobley HL (2004) Pathogenic Escherichia coli. Nat Rev Microbiol 2: 123-140.

7. Levine MM (1987) Escherichia coli that cause diarrhea: enterotoxigenic, enteropathogenic, enteroinvasive, enterohemorrhagic, and enteroadherent. J Infect Dis 155: 377 389.

8. Gómez-Duarte OG, Bai J, Newell E (2009) Detection of Escherichia coli, Salmonella spp., Shigella spp., Yersinia enterocolitica, Vibrio cholerae, and Campylobacter spp. enteropathogens by 3-reaction multiplex polymerase chain reaction. Diagn Microbiol Infect Dis 63: 1-9.

9. Persson S, de Boer RF, Kooistra-Smid AMD, Olsen KEP (2011) Five commercial DNA extraction systems tested and compared on a stool sample collection. Diagn Microbiol Infect Dis 69: 240-244.

10. Stacy-Phipps S, Mecca JJ, Weiss JB (1995) Multiplex PCR assay and simple preparation method for stool specimens detect enterotoxigenic Escherichia coli DNA during course of infection. J Clin Microbiol 33: 1054-1059.

11. LaBarre P, Hawkins KR, Gerlach J, Wilmoth J, Beddoe A (2011) A simple, inexpensive device for nucleic acid amplification without electricity- toward instrument-free molecular diagnostics in low-resource settings. PLoS ONE. 6: e19738.

12. DANE. 2005. Censo General 2005.

13. Manrique-Abril FG, Tigne y Diane Bello SE, Ospina JM (2006) [Diarrhoea-causing agents in children aged less than five in Tunja, Colombia]. Rev Salud Publica (Bogota). 8: 8897.

14. Cáceres DC, Peláez D, Sierra N, Estrada E, Sánchez L (2006) [Burden of rotavirus-related disease among children under five, Colombia, 2004]. Rev Panam Salud Publica 20: 9-21.

15. Correa A, Solarte Y, Barrera J, Mogollón M, Gutiérrez MF (1999) [Molecular characterization of rotavirus in the city of Santafé de Bogotá, Colombia. Determination of the electrophenotypes and typing of a strain by RT-PCR]. Rev Latinoam Microbiol 41: 167-173.

16. Gutierrez MF, Matiz A, Trespalacios AA, Parra M, Riaño M, Mercado M (2006) Virus diversity of acute diarrhea in tropical highlands. Rev Latinoam Microbiol 48: 17-23.

17. Urbina D, Arzuza O, Young G, Parra E, Castro R (2003) Rotavirus type A and other enteric pathogens in stool samples from children with acute diarrhea on the Colombian northern coast. Int Microbiol 6: 27-32.

18. Urbina D, Rodríguez JG, Arzuza O, Parra E, Young G (2004) $\mathrm{G}$ and $\mathrm{P}$ genotypes of rotavirus circulating among children with diarrhea in the Colombian northern coast. Int Microbiol 7: 113-120.
19. Hidalgo M, Realpe ME, Muñoz N, Sicard D, Silva E, Agudelo CI, Castaneda E (2002) [Acute diarrhea outbreak caused by Shigella flexneri at a school in Madrid, Cundinamarca: phenotypic and genotypic characterization of the isolates]. Biomedica 22: 272-279.

20. Muñoz N, Realpe ME, Castañeda E, Agudelo CI (2006) [Characterization by pulsed-field gel electrophoresis of Salmonella typhimurium isolates recovered in the acute diarrheal disease surveillance program in Colombia, 19972004]. Biomedica 26: 397-407.

21. Gómez-Duarte OG, Arzuza O, Urbina D, Bai J, Guerra J, Montes O, Puello M, Mendoza K, Castro GY (2010) Detection of Escherichia coli enteropathogens by multiplex polymerase chain reaction from children's diarrheal stools in two Caribbean-Colombian cities. Foodborne Pathog Dis 7: 199-206.

22. Trabulsi, L.R., R. Keller, T.A. Tardelli Gomes. 2002. Typical and atypical enteropathogenic Escherichia coli. Emerging Infect. Dis. 8: 508-513.

23. Rúgeles LC, Bai J, Martínez AJ, Vanegas MC, Gómez-Duarte OG (2010) Molecular characterization of diarrheagenic Escherichia coli strains from stools samples and food products in Colombia. Int J Food Microbiol 138: 282-286.

24. World Health Organization (2005) The treatment of diarrhoea: a manual for physicians and other senior health workers. 4th revision. Geneva: Dept. of Child and Adolescent Health and Development World Health Organization.

25. Consejo Nacional de Politica Economica y Social (CONPES) (2005) Plan de accion para la focalizacion de los subsidios para servicios publicos domiciliarios.

26. Koneman E (1997) Color atlas and textbook of diagnostic microbiology. 5th ed. Philadelphia: Lippincott.

27. Nguyen TV, Le Van P, Le Huy C, Gia KN, Weintraub A (2005) Detection and characterization of diarrheagenic Escherichia coli from young children in Hanoi, Vietnam. J Clin Microbiol 43: 755-760.

28. Vidal M, Kruger E, Durán C, Lagos R, Levine MM, Prado, V, Toro C, Vidal R (2005) Single multiplex PCR assay to identify simultaneously the six categories of diarrheagenic Escherichia coli associated with enteric infections. J Clin Microbiol 43: 5362-5365.

29. Huilan S, Zhen LG, Mathan MM, Mathew MM, Olarte J, Espejo R, Khin Maun U, Ghafoor MA, Khan MA, Sami Z, (1991) Etiology of acute diarrhoea among children in developing countries: a multicentre study in five countries. Bull World Health Organ 69: 549-555.

30. Maranhão HS, Medeiros MCC, Scaletsky ICA, FagundesNeto U, Morais MB (2008) The epidemiological and clinical characteristics and nutritional development of infants with acute diarrhoea, in north-eastern Brazil. Ann Trop Med Parasitol 102: 357-365.

31. Levine MM, Ferreccio C, Prado V, Cayazzo M, Abrego P, Martinez J, Maggi L, Baldini MM, Martin M, Maneval D (1993) Epidemiologic studies of Escherichia coli diarrheal infections in a low socioeconomic level peri-urban community in Santiago, Chile. Am J Epidemiol 138: 849-869.

32. Estrada-Garcia T, Lopez-Saucedo C, Thompson-Bonilla R, Abonce M, Lopez-Hernandez D, Santos JI, Rosado JL, DuPont HL, Long KZ (2009) Association of diarrheagenic Escherichia coli Pathotypes with infection and diarrhea among Mexican children and association of atypical Enteropathogenic E. coli with acute diarrhea. J Clin Microbiol 47: 93-98. 
33. Paniagua GL, Monroy E, García-González O, Alonso J, Negrete E, Vaca S (2007) Two or more enteropathogens are associated with diarrhoea in Mexican children. Ann Clin Microbiol Antimicrob 6: 17.

34. Rivas M, Miliwebsky E, Chinen I, Roldán CD, Balbi L, Garcia B, Fiorilli G, Sosa-Estani S, Kincaid J, Rangel J, Griffin PM, Case-Control Study Group (2006) Characterization and epidemiologic subtyping of Shiga toxinproducing Escherichia coli strains isolated from hemolytic uremic syndrome and diarrhea cases in Argentina. Foodborne Pathog Dis 3: 88-96.

35. Wennerås C, Erling V (2004) Prevalence of enterotoxigenic Escherichia coli-associated diarrhoea and carrier state in the developing world. J Health Popul Nutr 22: 370-382.

36. Flores J, DuPont HL, Jiang Z-D, Belkind-Gerson J, Mohamed JA, Carlin LG, Padda RS, Paredes M, MartinezSandoval JF, Villa NA, Okhuysen PC (2008) Enterotoxigenic Escherichia coli heat-labile toxin seroconversion in US travelers to Mexico. J Travel Med 15: 156-161.

37. Long KZ, Santos JI, Rosado JL, Lopez-Saucedo C, Thompson-Bonilla R, Abonce M, DuPont HL, Hertzmark E, Estrada-Garcia T (2006) Impact of vitamin A on selected gastrointestinal pathogen infections and associated diarrheal episodes among children in Mexico City, Mexico. J Infect Dis 194: 1217-1225.

38. Rao MR, Abu-Elyazeed R, Savarino SJ, Naficy AB, Wierzba TF, Abel-Messih I, Shaheen H, Frenck RWJr, Svennerholm AM, Clemens JD (2003) High disease burden of diarrhea due to enterotoxigenic Escherichia coli among rural Egyptian infants and young children. J Clin Microbiol 41: 4862-4864.

39. Chowdhury F, Rahman MA, Begum YA, Khan AI, Faruque ASG, Saha NC, Baby NI, Malek MA, Kumar AR, Svennerholm AM, Pietroni M, Cravioto A, Qadri F (2011) Impact of rapid urbanization on the rates of infection by Vibrio cholerae $\mathrm{O} 1$ and enterotoxigenic Escherichia coli in Dhaka, Bangladesh. PLoS Negl Trop Dis 5: e999.

40. Hyams KC, Bourgeois AL, Merrell BR, Rozmajzl P, Escamilla J, Thornton SA, Wasserman GM, Burke A, Echeverria P, Green KY (1991) Diarrheal disease during Operation Desert Shield. N Engl J Med 325: 1423-1428.

41. Shah N, DuPont HL, Ramsey DJ (2009) Global etiology of travelers' diarrhea: systematic review from 1973 to the present. Am J Trop Med Hyg 80: 609-614.
42. Bueris V, Sircili MP, Taddei CR, dos Santos MF, Franzolin MR, Martinez MB, Ferrer SR, Barreto ML, Trabulsi LR (2007) Detection of diarrheagenic Escherichia coli from children with and without diarrhea in Salvador, Bahia, Brazil Mem Inst Oswaldo Cruz 102: 839-844.

43. Moreno ACR, Filho AF, Gomes Tdo A, Ramos STS, Montemor LPG, Tavares VC, Filho Ldos S, Irino K, Martinez MB (2010) Etiology of childhood diarrhea in the northeast of Brazil: significant emergent diarrheal pathogens. Diagn Microbiol Infect Dis 66: 50-57.

44. Pérez C, Gómez-Duarte OG, Arias ML (2010) DiarrheagenicEscherichia coli in children from Costa Rica. Am J Trop Med Hyg 83: 292-297.

45. Murray BE, Mathewson JJ, DuPont HL, Ericsson CD, Reves RR (1990) Emergence of resistant fecal Escherichia coli in travelers not taking prophylactic antimicrobial agents. Antimicrob Agents Chemother 34: 515-518.

46. Brzuszkiewicz E, Thürmer A, Schuldes J, Leimbach A, Liesegang H, Meyer FD, Boelter J, Petersen H, Gottschalk G, Daniel R (2011) Genome sequence analyses of two isolates from the recent Escherichia coli outbreak in Germany reveal the emergence of a new pathotype: Entero-AggregativeHaemorrhagic Escherichia coli (EAHEC). Archives of Microbiology 193:883-891.

47. Rasko DA, Webster DR, Sahl JW, Bashir A, Boisen N, Sheutz F, Paxinos EE, Sebra R, Chin CS, Iliopoulos D, Klammer A, Peluso P, Lee L, Kislyuk AO, Bullard J (2011) Origins of the E. coli strain causing an outbreak of hemolyticuremic syndrome in Germany. N Engl J Med 365: 709-717.

\section{Corresponding author}

Oscar G. Gómez-Duarte

International Enteric Vaccine Research Program

Division of Pediatric Infectious Diseases

Vanderbilt University School of Medicine

116121 st Ave, D-7235 MCN

Nashville, TN 37232-2581

Telephone: 615-343-6738

Fax: 615-936-7800

Email: Oscar.gomez@vanderbilt.edu

Conflict of interests: No conflict of interests is declared. 